\title{
PIACI KOCKÁZAT ÉS SZÁMSZERŰSÍTÉSE AZ R SZOFTVERREL
}

\section{Szerző:}

Pšenák Peter

Univerzita Komenského v Bratislave

(Szlovákia)

Szerző e-mail címe:

petkoneo@gmail.com

\section{Lektorok:}

Pšenáková Ildikó (PhD)

Trnavská Univerzita v Trnave

(Slovakia)

Szabó Tibor (PhD)

Univerzita Konštantína Filozofa v

Nitre (Slovakia)

...és további két anonim lektor

\section{Absztrakt}

Az elmúlt 30 évben a gazdasági válságok gyakorisága bizonyítottan nőtt. Tekintettel erre a tényre a pénzügyi szférában megnőtt a piaci kockázatelemzés fontossága. A gyakorlatban a VaR (Value at Risk) a leggyakrabban használt módszer a kockázat modellezésére. A publikációnk a piaci rizikó felmérési módszereit mutatja be, néhány gyakorlati példával azoknak előnyeivel és hátrányaival az $\mathrm{R}$ szoftver használata segítségével.

Kulcsszavak: pénzügy, R szoftver, rizikó, VaR

Diszciplina: pénzügyi matematika

\section{Abstract}

QUANTIFICATION OF MARKET RISK WITH THE R SOFTW ARE

The frequency of economic crises has been shown to increase over the last 30 years. In view of this fact, the importance of market risk analysis in the financial sector has increased. In practice, $\mathrm{VaR}$ (Value at Risk) is the most commonly used method for modeling risk. Our publication presents methods for assessing market risk, with some practical examples of their advantages and disadvantages using $\mathrm{R}$ software.

Keywords: finance, $\mathrm{R}$ software, risk, $\mathrm{VaR}$

Disciplines: financial mathematics

Pšenák Peter (2020): Piaci kockázat és számszerűsítése az R szoftverrel. Mesterséges intelligencia - interdiszciplináris folyóirat, II. évf. 2020/2. szám. 9-21. doi: 10.35406/MI.2020.2.9 
Az 1990-es évek óta a világgazdaságot számos gazdasági válság jellemezte, például az ázsiai válság 1997-ben, egy évvel később az Oroszországi válság, 2000-ben a jól ismert dot-com válság és 2008-ban a pénzügyi válság, amely számos országot érintett Amerikától Európáig. Az említett események azt bizonyítják, hogy az elmúlt 30 évben a gazdasági válságok gyakorisága nőtt.

Tekintettel a fenti tényekre a pénzügyi szférában megnőtt a piaci kockázatelemzés fontossága. A témával foglalkozó szakértők legújabb munkáikban és publikációikban a figyelmük középpontjában észrevehető a változás e tevékenység irányában. Míg a közelmúltban a pénzügyi elemzők elsősorban a pénzügyi hozamok átlagértékének $(\mu)$ modellezésére összpontosítottak, jelenleg a standard eltérés ( $\sigma)$ modellezése jelenik meg gyakrabban, mint a legfontosabb témakör.

Logikus, hogy ki kellett dolgozni a pénzügyi modellezés új módszereit és technikáit, amelyek többek között a pénzügyi piacok empirikusan megfigyelhető extrém ingadozásaival foglalkoznak. Ezeket az ingadozásokat leggyakrabban válságok vagy különféle gazdasági sokkok okozzák. Cikkünk ezekkel a módszerekkel és azok elemzésével foglalkozik és bemutatja azoknak használatát az $\mathrm{R}$ szoftver segítségével.

\section{Piaci kockázat}

Minden gazdaságilag aktív személy vagy üzleti szervezet folyamatosan ki van téve bizonyos szintű, eltérő természetű kocká- zatnak. Egyes szervezetek csak passzív módon fogadják be a különböző kockázatokat anélkül, hogy megpróbálnák kezelni a helyzetet. Mások bizonyos mértékben számítanak ezekre a kockázatokra és igyekeznek legalább felmérni a különböző lehetőségeket, de nem próbálják irányítani őket. Vannak, akik arra törekszenek, hogy aktívan figyeljék a lehetséges kockázatokat és lehetőség szerint számszerūsítsék és/vagy kezeljék azokat. Ezek képesek a jövőbeli kockázatokat nem csak feltérképezni, hanem előre látni azokat és optimálisan kezelni őket.

A folyamatot, amellyel különféle kockázatokat azonosítunk, mérünk és irányítunk, kockázatkezelésnek nevezünk. A kockázatkezelés célja elsősorban a gazdálkodó egység vagy szervezet pénzügyi teljesítményének javítása. Ugyanakkor célja az is, hogy üzleti partnereket biztosítson abban, hogy a nem kívánt veszteségekkel szemben a jövőben védve lesznek (Gabriel C. \& Baker C., 1980; Sivák et al., 2018).

A pénzügyi kockázat többféle módon is meghatározható. Egy gazdasági szervezet potenciális pénzügyi veszteségének tekintjük azt, amelyet a vártnál eltérô pénzügyi piac mozgása okozhat (Holton, 2004). Ebbe nem számítjuk be a már létező veszteséget, amelyet már elszenvedett a szervezet, hanem a jövőben a pénzügyi piacon várható veszteséget értjük, feltéve, hogy az adott pénzügyi portfóliójukat használják. A kockázatokat egy üzleti szervezet szempontjából üzleti és nem üzleti kockázatra osztjuk. 
Az üzleti kockázat egy olyan fajta kockázat, amely azon az áru és szolgáltatás piacán jöhet létre, amelyen a vállalat működik, beleértvé az összes olyan piacot, amelyen a vállalat múködik (ha egy transznacionális vállalatról van szó). Magába foglalja az áruk és/vagy szolgáltatások és azok alkotóelemeit (tervezés, ár, design, minőség), valamint a különféle makrogazdasági kockázatokat is. A makrogazdasági kockázatok közé bevon-hatjuk többek között a jelenlegi üzleti ciklusnak, az állam fiskális politikájának és egyéb összetevőknek a kockázatát is.

A nem üzleti kockázathoz minden egyéb olyan kockázat tartozik, amely nem kereskedelmi működésből jön létre (Sivák et al., 2018).

A pénzügyi kockázat az üzleti kockázatok közé tartozik, amelyeket a következő kategóriákba osztjuk:

- kamatlábkockázat,

- piaci kockázat,

- likviditási kockázat,

- devizakockázat (Horcher, 2011; Jílek, 2004).

Ebben a cikkben csak a piaci kockázattal foglalkozunk. A piaci kockázat fó változatai közé tartoznak a kamatláb-, részvény-, áru- és devizakockázatok (Dowd, 2005). Azok a pénzügyi eszközök, amelyek egy üzleti egység portfóliójában vannak, és amelyek piaci kockázatnak vannak kitéve, eltérő természetűek lehetnek. Ide tartoznak:

- hitelek,

- részvény értékpapírok,
- kötvények,

- devizában tartott források stb.(Sivák et al., 2018).

A piaci kockázat meghatározásához számos olyan paraméter értékét kell megbecsülni, amely változást okozhat a kockázat mértékében. Ezeknek a becsléseknek a lehető legpontosabbaknak kell lenniük, hogy a pénzügyi kockázatot a lehető legkisebb eltéréssel lehessen azonosítani.

\section{Kockázatmérés}

A kockázatmérés a pénzügyi eszközök értékelésének fontos része. Ha az egyéni pénzügyi eszközök kockázatát helytelenül mérik, akkor az egész eszközportfólió értékét tévesen értékelik. Ez az ökonómiai egység pénzügyi forrásai helytelen elosztását eredményezi. Ezért a célunk ezeknek a helyzeteknek a lehető legjobb felmérése és lehetséges elkerülése.

Figyelembe véve egy pénzügyi eszköz kockázatát azt állíthatjuk, hogy a számítások alatt figyelembe vett kockázati tényezők az adott eszköz ára és az ár időbeli változása. A gyakorlatban a VaR (Value at Risk) a leggyakrabban használt módszer a kockázat modellezésére. Ez egy statisztikai egység a portfólió piaci kockázatának mérésére. A VaR alapja a diverzifikáció hatása, valamint a teljes tőke és az adósság aránya. Más szavakkal, a VaR számításában a pozíciókat a piaci értékeik alapján értékelik, majd egy valószínűségi keretet követnek a pozíció-értékek 
lehetséges változásainak becslé-sére a kiválasztott konfidencia inter-vallumon (Sivák et al., 2018). Az adott $\alpha(0,1)$ megbízhatósági intervallumra a VaR-t úgy határozzuk meg, mint a veszteség ( $l$ lehető legkisebb értékét, miközben az l-nél magasabb veszteségeknek a veszteség valószínűsége (L) nem haladja meg az (1 $\alpha)$ :

$$
\begin{array}{r}
\operatorname{VaR}_{\alpha}=\inf (1 \in \mathbb{R}: \mathrm{P}(\mathrm{L}>\mathrm{l}) \leq 1-\alpha) \\
=\inf \left(\mathrm{l} \in \mathbb{R}: \mathrm{F}_{\mathrm{L}}(\mathrm{l}) \geq \alpha\right)
\end{array}
$$

A VaR eredménye egy szám, amely a tőke azt a mennyiségét fejezi ki, amelyet egy üzleti egység elveszíthet egy meghatározott valószínűséggel (Sivák et al., 2018).

\section{A VaR számításának módszerei}

A VaR számításának három fó módszere van:

1. Historikus VaR

2. Parametrikus - kovariancia mátrix

3. Monte-Carlo szimuláció (Sivák et al., 2018)

A fenti módszerek mindegyike más módosított változattal is rendelkezik.

A VaR-hoz való első megközelítés alapvetően egy tradicionális megközelítés a nem-parametrikus VaR alapján, amelyet a szakirodalomban az 1990-es évek elején még ,igazi VaR”-nak neveztek. Ha megfelelően nagy mennyiségű historikus adattal rendelkezik a befektető választhat egy nem-parametrikus VaR-becslési módszert, amely egy korábbi eloszlást és egy kiszámított valószínűségi kvantilist hasz- nál. A negatív hozam egy előre meghatározott számértéknél (többnyire 95\%, 99\%, 99,9\%) valójában egy VaR nemparaméteres becslése egy adott szignifikanciaszinten, amelynek kiszámítása nagy mennyiségű adatnál elvileg egyszerű (Sivák et al., 2018). Ha az idősor hozamokat a legkisebbtől a legnagyobbig rendezzük, és kiválasztjuk a választott kvartilis értékét, akkor megkapjuk a his-torikus VaR-t. Ez a módszer azonban csak a korábbi adatok alapján adja meg a keresett értékel, és nem modellez semmi-lyen paramétert a jövőre nézve, ezért nem parametrikus VaR-nak nevezzük.

A gyakorlatban gyakrabban használják ugyanezen megközelítés kiszámítási módszerének parametrikus változatát. A módszer nem parametrikus változatát azonban továbbra is használják, elsősorban a VaR számítási módszerek más típusaival való összehasonlításhoz, mint egy benchmark módszert.

A parametrikus VaR kiszámításának megközelítését 1994-ben tették közzé a J. P. Morgan által meghatározott és később módosított kockázati mutatókkal (Morgan, 1996).

A VaR paraméteres átlagának becslésére szolgáló módszerért, amelyet bevezettek nevezik a gyakorlatban azóta általában VaR-nak, és a pénzügyi elemzők által használt számos statisztikai szoftverben is ez alatt a név alatt vezették be. Az ilyen típusú VaR számítás pontosabban becsüli meg a kvantilis alatti disztribúció eloszlást, figyelembe véve, annak jellemzőivel. Ha az eszközök eloszlása nagyon eltér a normális 
eloszlástól, akkor az ezzel a módszerrel kiszámított kockázatbecslés továbbra sem kielégítő, és a pontossága nem megfelelő.

Ezeknek a problémáknak a kiküszöbölésére szimulációkat és az azt követő VaR kiszámítását alkalmazzák a normál eloszlás vagy az általános Pareto eloszlásnak megfelelően. Utólagos tesztelési technikák is felhasználhatók a modellezett VaR pontosságának felmérésére (back-testing) a historikus adatok alapján. A nem parametrikus és a parametrikus VaR kiszámításának különféle módszerei jelenleg is fejlesztés alatt állnak, és különböző fejlesztéseivel megpróbálják a tudósok kiküszöbölni a modell néhány negatívumát (Almeida, et al., 2017; Kwin T et al., 2017; Nieto Rosa \& Ruiz, 2016).

A rizikó számításának egy másik lehetősége a marginális VaR. Ennél a rizikó megközelítésnél bootstrapping metódussal számolnak, azaz meghatá-rozzák az egész portfólió VaR értékét az összes értékpapírral együtt, és utána egyenként kihagynak egy darabot közülük és újra számolják a portfólió $\mathrm{VaR}$ értékét. Ily módon külön megkapjuk az egyes eszközök VaR-ját, és ezzel egyidejűleg a teljes portfólió VaR-jához való hozzájárulását is (Rau-Bredow, 2002).

A koherens kockázatértékelés egyik jellemzője az szubadditivitás feltételezése (a portfóliókockázatok nem haladhatja meg az egyes összetevők kockázatainak összegét). A marginális VaR kiszámításakor ezt a feltételt nem tartjuk figyelemben, ezért nem tekinthetők a portfo- liókockázat teljesen koherens modelljének (Artzner et al., 1998).

A szubadditivitás feltételnek fenntartása érdekében egy másik típusú $\mathrm{VaR}$ metódus is létezik, az úgynevezett komponens $\mathrm{VaR}$. A komponens VaR-ban az egyes összetevők (a vizsgált portfólióba tartozó eszközök) VaR értéke megegyezik a portfólió teljes VaR összegével (Chen et al., 2007).

Vannak teljesen alternatív módszerek a kockázat kiszámítására is, amelyek nem is veszik figyelembe a kvartilisokat mint a legmegfelelőbb kockázatbecslési paramétert (Hamidi et al., 2015). Ebben a cikkben nem foglalkozunk ezekkel a metódusokkal és ezzel a kérdéssel.

Az átlagos kockázati érték parametrikus vagy nem-parametrikus változatainak hagyományos megközelítésének korlátozásai a szimmetrikus eloszlási függvény használatához kapcsolódnak. Ezek a korlátozások akkor is felmerülnek, ha a számításokat kiigazítjuk olyan eszközök esetében, amelyek szignifikánsan szokatlan (ferde és/vagy hegyes) és nem normális eloszlással rendelkeznek.

A klasszikus VaR jelentôs és gyakori hibáinak eltüntetésének egyik módja az lehet, ha közvetlenül a VaR számításába beleszámítjuk a vizsgált eszközök statisztikai eloszlásának magasabb statisztikai momentumait. Ez az alternatív VaR magába foglalja a ferdeséget és az élességet, amit a Cornish-Fisher expanzió alkalmazásával érnek el. A kapott VaR változatát „Cornish-Fisher VaR2” -nak vagy „Modified VaR”-nak (mVaR) 
nevezzük. A módosított VaR ugyanazokat az eredményeket nyújtja, mint a hagyományos parametrikus $\mathrm{VaR}$, ha a pénzügyi eszközök hozamának eloszlása normális, ezért felhasználható közvetlen helyettesítésként.

A tudományos irodalom tartalma alapján arra a következtetésre lehet jutni, hogy a módosított VaR kiváló megoldás a kockázatmérés problémájára még a nem szabványos eloszlások esetén is. Más VaR számítási metódusok alternatívájaként is felhasználható, mint benchmark érték. (Favre \& Galeano, 2002; Pfaff, 2016)

A módosított VaR értéket a következőképpen van meghatározva:

$$
\begin{aligned}
m V a R_{a}=\operatorname{VaR}_{a}+ & \frac{\left(q_{\alpha}^{2}-1\right) S}{6}+\frac{\left(q_{\alpha}^{3}-3 q_{\alpha}\right) K}{24} \\
& -\frac{\left(2 q_{a}^{3}-5 q_{\alpha}\right) S^{2}}{36}
\end{aligned}
$$

ahol S az eloszlás ferdesége,

$\mathrm{K}$ az élesség,

$\mathrm{q}_{\alpha}$ a standard normál véletlen változó kvartilje a szinttel.

Ez a megközelítés konzervatívabb VaR becsléshez vezet, mint más módszerek.

A modell számos módosítása és folyamatos átalakítása ellenére a VaR-t továbbra is gyakran negatívan bírálják a szakértők. A VaR pontatlan kockázat becslései leggyakrabban a negatív érvek között jelennek meg. Empirikus bizonyí-tékok arra utalnak, hogy a különféle $\mathrm{VaR}$ módszerek jelentősen eltérő becsléseket adhatnak a kockázat magasságáról és értékéről. További hátrány, hogy a VaR modellek jelentős végrehajtási kockázat- nak vannak kitéve, így még az elméletileg ugyanazok a modellek is meglehetősen eltérő becsléseket adhatnak más más programozási nyelvben. Az általános VaR kérdés másik problémája az, hogy a kockázat endogén. Ez alatt azt értjük, hogy a kereskedőket ösztönzi az olyan pozíciók keresésére és üzletelése, amely-ekben a kockázat túlértékelt vagy alul-értékelt, így nagyobb kockázatot vállal-hatnak magukra, mint maga a VaR becsült értéke.

A VaR modellek nem veszik figyelembe a többi kereskedő reakcióját $z$ üzletelt pozíciókra, ezért lefelé lehetnek torzítva az értékeik (Pfaff, 2016).

Egyes VaR-szerzők ezzel szemben támogatják és állítják, hogy ez a helyes értékelési változó, de helytelenül használják fel. Azt is elismerik, hogy nem tudják kizárni a VaR modellek összes negatívumát, és rámutatnak a pénzügyi szabályozási rendszer hibáira is (Dowd, 2005).

A kritikusok igyekeznek kerülni a VaR használatát a kockázat mérésére, mivel nem ad meggyőző becslést a veszteség nagyságáról, ha a veszteség nagyobb, mint a választott konfidenciaszintnél becsült VaR. Tehát, ha az akció egész évben pozitív hozamot eredményez és csak 10 nap alatt veszteséges, akkor nem az érdekel, milyen az a nap legmagasabb szintű vesztesége, hanem az év azon napjainak átlagos vesztesége. Ezt a problémát az „expected shortfall” modellel lehet megoldani (Pfaff, 2016).

Ezzel a modellel a publikációnkban nem fogunk foglalkozni. 


\section{Példa a gyakorlatból}

A modell bemutatásához szabadon rendelkezésre álló adatokat fogunk felhasználni, amelyeket a pénzügyi webhelyek különféle API-jaiból (Application Programming Interface) kapunk meg. Elsődleges forrásként a Yahoo Finance API-ját használjuk, amely különféle ingyenes pénzügyi adatokhoz enged hozzáférni. Ezen kívül több más weboldal API-ját is felhasználtuk az adatok ellenőrzésére. Ide tartoznak:

- Federal Reserve Economic Data

- Oanda

- Alpha vantage

Ezek a weboldalak naprakész adatokkal szolgálnak, amelyeknek nagysága elegendő ahhoz, hogy a gazdasági ciklusokból származó pénzügyi hozamok ciklikus jellegét figyelembe tudjuk venni. A pénzügyi kockázat elemzéséhez ezt követően ezen eszközök hozamait használjuk, amelyeket a kiválasztott statisztikai programban könnyen kiszámolhatunk.

A szükséges kockázatbecslések kiszámításához az R programozási nyelvet használjuk, amely nagyon rugalmas és alkalmas pénzügyi elemzésre. Valójában az $\mathrm{S}$ nyílt forráskódú verziója. Számos előnye van, amelyet más hasonló alkalmazások nem nyújtanak. Az R programozási nyelv képes nagy mennyiségû adat kezelésére, amelynek maximális kapacitása gyakorlatilag a használt számítógép memóriakapacitásával van korlátozva. Más szoftverrel ellentétben nem tartalmaz szerkesztőprogramot, amely megtakarítja a számítógép memóriáját azáltal, hogy nem jeleníti meg az összes adatot állan-dóan az eszköz kijelzőjén (Peter Pšenák \& Kováč, 2019).

Az $\mathrm{R}$ forráskódokat lehetséges különböző adathalmazokkal újra használni. A forráskódok a CRAN weboldalon szabadon elérhető csomagokban érhetők el, és ezek a csomagok több funkcióval is felhasználhatók. Ilyen esetekben csak a forráskód linket kell átírni egy másik adathalmazhoz, és az eredmények automatikusan megjelennek a képernyőn.

Az $\mathrm{R}$ programozási nyelv további előnye az adatok átfogó megjelenítése egyszerű grafikus ábrázolás segítségével. $\mathrm{Ez}$ azt is lehetôvé teszi, hogy az általunk választott adatokat megjelenítsük. Az $\mathrm{R}$ szoftver intuitív módon használható, így könnyen megtanulható. A dplyr és goplot2 néven ismert ingyenes bővítménycsomagok szintén letölthetők a weboldalon, és rengeteg lehetőséget kínálnak az adatok kezelésére és megjelenítésére. Ezek a csomagok nagyon hasznosnak bizonyulnak az adatok elemzésénél és azok megjelenítésének a feldolgozásában.

Végül, de nem utolsósorban, az R olyan ingyenes alkalmazás, amelyet bárki bármikor letölthet és felhasználhat. Rendelkezésre áll az R-studio szerkesztő is, amely megkönnyíti az $\mathrm{R}$ programozási nyelv használatát (Péter Pšenák \& Pšenáková, 2018). Az R program ezen alkotóelemeit különféle pénzügyi és nem pénzügyi jellegú elemzésekhez használják (Mitková et al., 2018; Péter Pšenák et al., 2018a, 2018b). Programozási nyelvként is hasz-nálható különféle weboldalak létreho-zására. 
Például ezt a funkcióját egy olyan webhely létrehozására is fel lehet használni, amelyet az online pénzügyi management tanítására használtak (Péter Pšenák et al., 2019).

\section{Eredmények és megvitatás}

Elsősorban az Apple akcióit fogjuk tanulmányozni. Az akciót preferenciaként választottuk és mint megfelelő benchmark értékpapírt a pénzügyi piac IT szektorából. Az értékeket 1990 elejétől egészen 2020 április végéig analizáljuk (1. ábra). Érdekességként az adat végén a Covid-19 vírus „erejére” is vethetünk egy pillantást.
Elsősorban tekintsük meg az Apple akciói értékét az első ábrán. Eleinte alacsony értékeken mozgott, utána 2008 körül a cég értéke elkezdett nőni. Ennek az oka az, hogy abban az évben kezdték el a dividensek fizetését. Ezután nagyjából stabilan növekedett a trendje néhány ciklikus visszaeséssel. 2020 áprilisában a koronakrízisnek köszönhetőén az értéke elkezdet zuhanni.

Mint ahogy az elméleti szekcióban is említettük, az Apple értéke önmagában nem megfelelő érték a rizikó mérésére. A kockázatot a hozam adja meg, amelyet első rendű differenciálással érhetünk el. Ezt a 2 . ábrán láthatjuk.

\section{Apple rizikó számítása}

1. ábra: Az apple résquények ára 1990-tő 2020 áprilisáig (forrás: a Szerző)

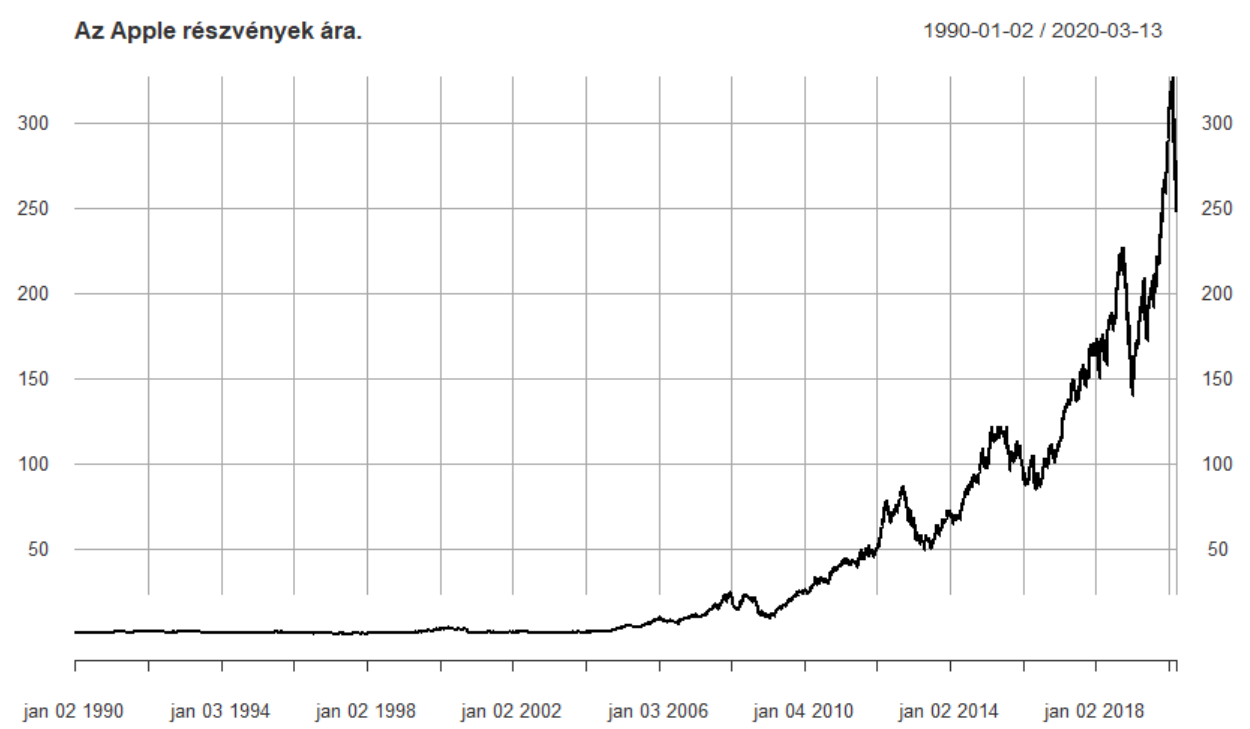


2. ábra: Apple résquény hozama (forrás: a Szerzö)

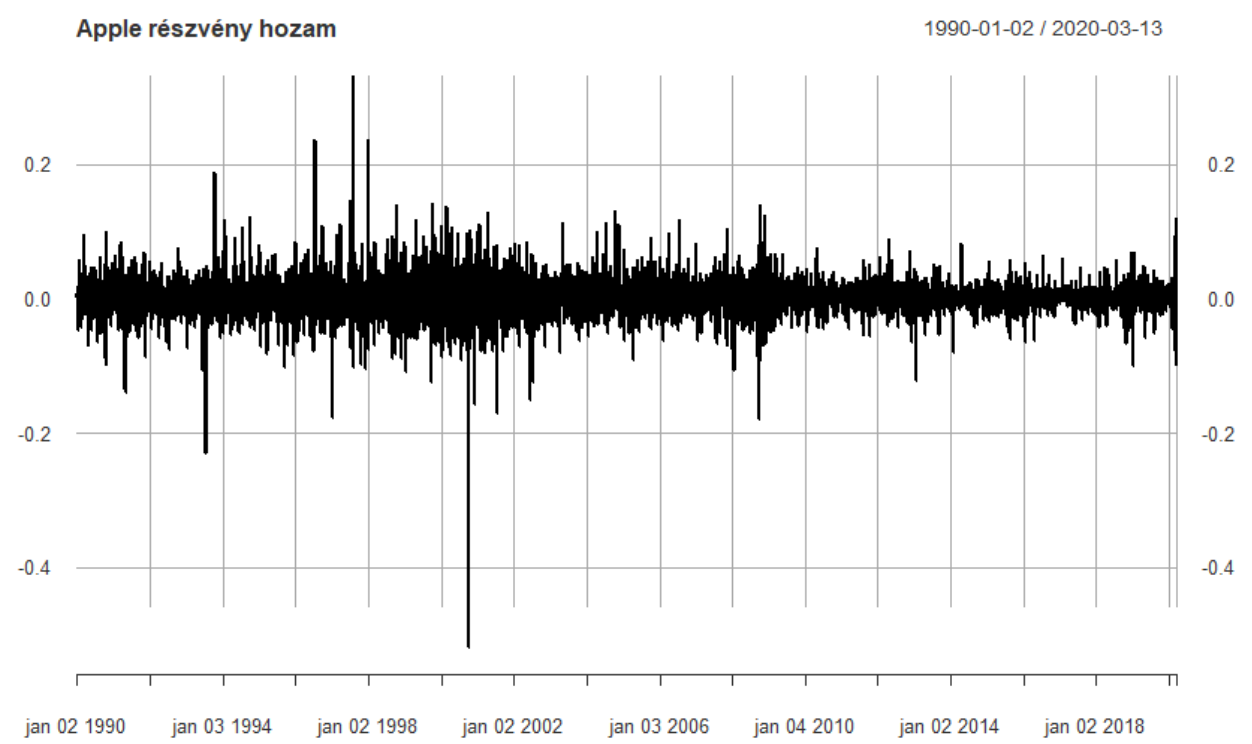

A 2. ábrán látthatjuk az Apple határozása, mint egy kvantil értéke volatilitását is és az úgynevezett ,,volatility clustering" -et, az-az, hogy az alacsony szintű volatilitás ideje cserélődik a magasabb szintű volatilitás ideével. Ezek az adatok már készen állnak a VaR kiszámítására.

Elsősorban a historikus VaR-t számoltuk ki. Ez a nem paraméteres változata a meglehetősen hosszú, nagymennyiségű historikus adatunkra. Különböző értékek mellett láthatjuk, hogy a $\mathrm{VaR}$ milyen (általában) pozitív számot eredményez. A gyakorlati szakemberek azzal érvelnek, hogy a VaR veszteséget jelöl, és negatív számnak kéne lennie. A publikációnkban úgy döntöttünk, hogy pozitív értékekként fogjuk a VaR-t a táblázatokban feltüntetni, úgy ahogy maga a modell adja meg.

Az 1. táblázatban az Apple részvény VaR értékeit mutatjuk be különböző szignifikancia értékeknél. A gyakorlatban a $\mathrm{p}=0,999$ statisztikai szignifikanciával módon mozog. A VaR matematikai meg-

1. táblázat: Apple részৃvény $V$ aR értékei különböző szignifikancia értékeknél (forrás: a Sz̨erzó)

\begin{tabular}{cccc}
\hline VaR & $\mathrm{p}=0.95$ & $\mathrm{p}=0.99$ & $\mathrm{p}=0.999$ \\
\hline Historikus & 0.041 & 0.071 & 0.135 \\
\hline
\end{tabular}


dolgoznak, tehát a lehető legkonzervatívabb lehetőséggel. Magát a VaR értékét úgy interpretálhatjuk. A mi esetünkben éves VaR értékeket számítottunk ki, tehát a $\mathrm{p}=0,95$ értékét úgy interpretálhatjuk, hogy a következő évben 5\% -os esély van arra, hogy a portfólió értékének több mint 4,1\% -át elveszíthetjük. Másképpen fogalmazva azt is mondhatjuk, hogy 95\% esély van arra, hogy a portfólió kevesebb, mint 4,1\% -ot veszít az értékéből. Ez a portfólió csak az Apple akciót tartalmazza.

Másképp is meg lehet fogalmazni a VaR érték interpretációját. Konkrétan pénz értékben: például, ha a portfóliónkban 1 millió dollár van befektetve azt mondhatjuk, hogy 95\% esély van arra, hogy a portfóliónk értéke nem fog csökkeni 41000 dollárral egy év alatt. Maga egy akció hozamának a VaR kiszámítása nem elegendő egy portfólió összeállításához. Ahhoz, hogy portfólió szinten több akcióval mérhessük a VaR értékét az Apple akciói mellé az Amazon és a Microsoft akcióit is hozzászámítottuk.

\section{Portfolió rizikó}

A portfóliónkat többféle módszerrel analizáltuk. Az összes értéket 0,99 szignifikanciánál számítottuk ki. A 3. ábra mutatja be az általunk létrehozott portfólió akciói értékét 1990 elejétől 2020 áprilisáig.

Kiszámítottuk a nem paraméteres (a táblázatban historikus névvel) VaR-t minden egyes akció hozamára és az egész portfólióra is. Utána a parametrikus VaR metódust, amit egy normál felosztással modelleztünk (Gauss) és a módosított VaR-t is kiszámítottuk, ami magába foglalja a ferdeséget és az élességet, amit a Cornish-Fisher expanzió alkalmazásával ér el. Az eredményeket egy táblázatban mutatjuk be.

3. ábra: Altalunk létrehozott portfólió akeciói értékét (forrás: a Szerzố)

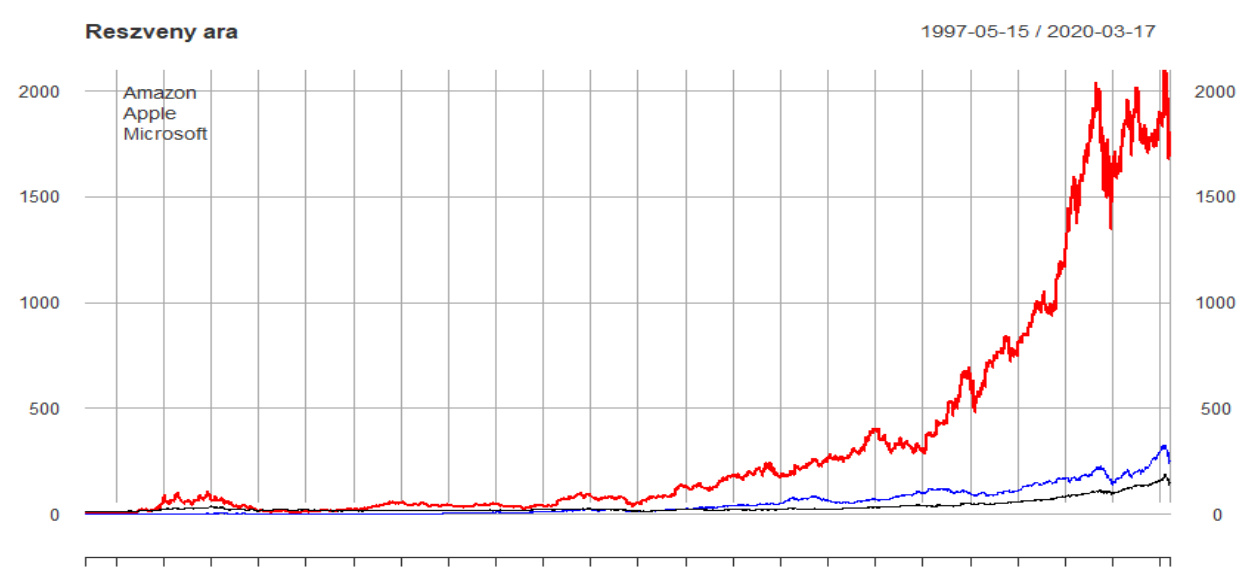


A portfóliót 25\% Apple, 50\% Amazon és 25\% Microsoft részvényekből adtuk össze. Ezt az elosztást nem optimalizáltuk, csak választottunk egy véletlenszerű eloszlást, amit vizsgálunk a klasszikus VaR-ok mellett. Elméletileg alacsonyabb eredményeket kellene adnia a portfólió VaR-nak, mint a különböző VaR értékeknek.

A 2. táblázatból láthatjuk, hogy a módosított $\mathrm{VaR}$ adja meg a legmagasabb értékeket, tehát a metódus a legkonzervatívabb mind közül. A nem paraméteres $\mathrm{VaR}$ pontosabb értékeket ad meg, mint a parametrikus a Microsoftnál, ugyanis a historikus értékek elegendően hosszú adathalmazt adnak ahhoz, hogy magába foglalhassa a nem teljesen normális disztribúció szerinti hozam viselkedését. A portfólió VaR majdnem minden egyes metódusnál alacsonyabb, mint az egyes érték papírok VaR-jai. Ez a diverzifikáció effektusa. Ami bizonyítja, hogy a VaR értékek külön-külön kiszámított értékpapírokra meghaladják a portfólió $\mathrm{VaR}$ értékeit.
Az összes értéket a 4. ábrán egy grafi-kon segítségével összegeztük, tisztán lát-szik, hogy a cornish-fisher modifikált VaR-ja magasabb étékeket ad az érték-papíroknál, míg a normális elosztású para-méteres $\mathrm{VaR}$ a legalacsonyabbakat. A gyakorlatban bizonyított, hogy az érték-papír hozamai nem normális elosztás szerint viselkednek, ezért a paraméteres $\mathrm{VaR}$ ez esetben is a benchmark értéket adta meg.

\section{Konklúziók}

A VaR érték gyakorlati hasznosságát bizonyítja a mai napig való használata, és a különböző metódusainak további fejlesztése. A cikkben bemutatott R szoftverrel való VaR értékek kiszámítása, alapul szolgálhat további vizsgálatokra, és benchmark értékeket adhat meg más VaR metódusok tesztelésére. Az $\mathrm{R}$ szoftver segítségével meglehetősen egyszerű ezeknek a metódusoknak a használata és az automatizálásukkal a jövőben akár olyna mesterséges intelligenciát is kilehetne fejleszteni, amely képes lenne rizikót bírálni.

2. táblázat: Portfólió V aR több fajta metódussal 0,99 szignifikancia értéknél (forrás: a Sžrző)

\begin{tabular}{ccccc}
\hline Típus & MSFT & AAPL & AMZN & Portfolió \\
\hline Historikus & 0.054 & 0.069 & 0.101 & 0.078 \\
Gauss & 0.045 & 0.062 & 0.085 & 0.046 \\
Módosított & 0.083 & 0.261 & 0.131 & 0.066 \\
\hline
\end{tabular}


4. ábra: Portfólió VaR több fajta metódussal 0,99 szignifikancia értéknél - grafikon (forrás: a Szerző")

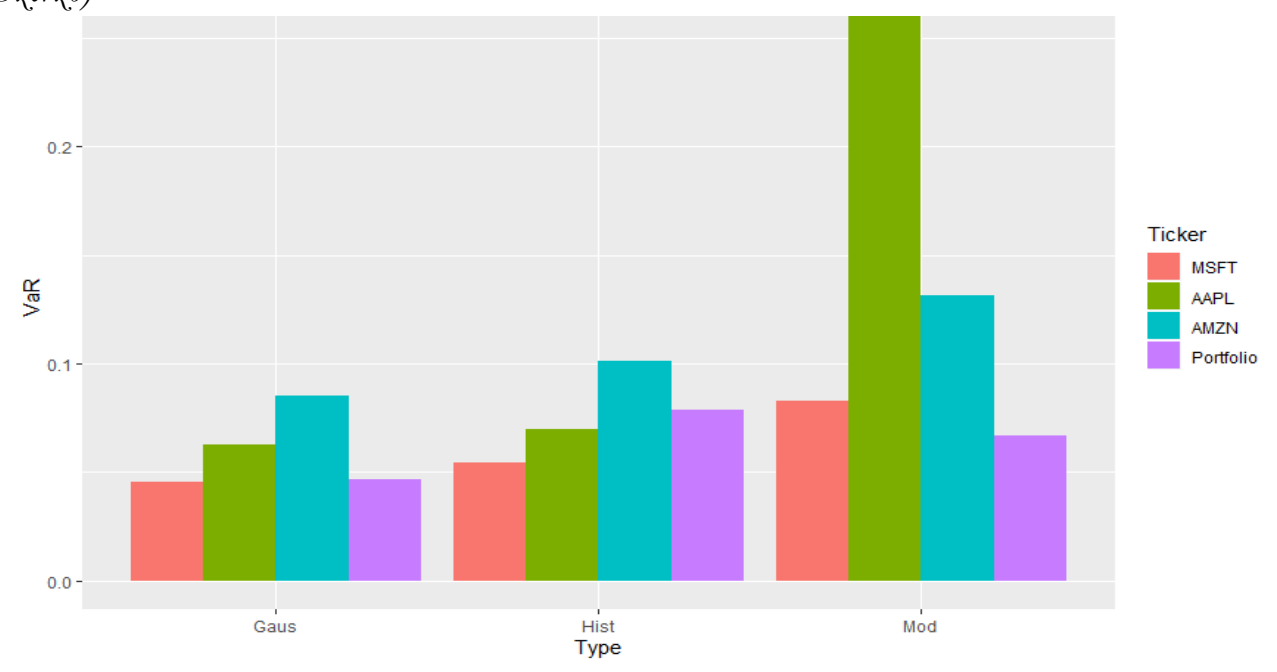

\section{Irodalom}

Almeida, C., Ardison, K., Garcia, R., \&

Vicente, J. (2017). Nonparametric Tail

Risk, Stock Returns, and the

Macroeconomy. Journal of Financial

Econometrics. Doi:

https://doi.org/10.1093/ijfinec/nbx0

$\underline{07}$

Artzner, P., Delbaen, F., Eber, J.-M., \&

Heath, D. (1998). Coherent measures of

risk. 24.

Chen, Y., Härdle, W., \& Spokoiny, V.

(2007). Portfolio value at risk based on independent component analysis.

Journal of Computational and Applied

Mathematics, 205(1), 594-607. Doi:

https://doi.org/10.1016/j.cam.2006.0

5.016

Dowd, Ke. (2005). Measuring Market Risk. John Wiley \& Sons Ltd, The Atrium, Southern Gate, Chichester.
Favre, L., \& Galeano, J.-A. (2002). MeanModified Value-at-Risk Optimization with Hedge Funds. The Journal of Alternative Investments, 5, 21-25. Doi: https://doi.org/10.3905/jai.2002.3190 $\underline{52}$

Gabriel C., S., \& Baker C., B. (1980). Concepts of Business and Financial Risk. American Journal of Agricultural Economics, 62. Doi: https://doi.org/10.2307/1240215 Hamidi, B., Hurlin, C., Kouontchou, P., \& Maillet, B. (2015). A DARE for VaR. Finance, Vol. 36(1), 7-38.

Holton, G. A. (2004). Defining Risk. Financial Analysts Journal, 60(6), 19-25. Doi: https://doi.org/10.2469/ faj.v60. n6.2669

Horcher, K. A. (2011). Essentials of Financial Risk Management. John Wiley $\&$ Sons. 
Jílek, J. (2004). Finanční rizikea. Grada Publishing.

Kwin T, L., Rong, Q., \& MacCarthy, B. (2017). Mean-VaR portfolio optimization: A nonparametric approach. European Journal of Operational Research, 751-766. Doi: https://doi.org/10.1016/j.ejor.2017.0 1.005.

Mitková, L., Pšenák, P., \& Kováč, U. (2018). University graduates in Slovakia in context of the Europe 2020 strategy. V Vision 2020:

Sustainable economic development and application of innovation management from regional expansion to global growth [elektronický dokument] (s. 8379-8388). International business information management association.

Morgan, J. P. (1996). RiskMetrics Technical Document. 296.

Nieto Rosa, M., \& Ruiz, E. (2016). Frontiers in VaR forecasting and backtesting. International Journal of Forecasting, 32(2), 475-501. Doi: https://doi.org/10.1016/j.ijforecast.2 $\underline{015.08 .003 .}$

Pfaff, B. (2016). Financial Risk Modelling and Porffolio Optimization with R.

Pšenák, Peter, \& Kováč, U. (2019). Usage of $\mathrm{R}$ for time series data analysis. Letöltés: 2020-03-14- Web:

http://didmattech.truni.sk/2019/proc eedings/\#psenak-ea-01

Pšenák, Péter, Kováč, U., Káčer, J., \& Skýpalová, M. (2018a). Impact of university degree on the labor market in Slovakia. Economic and Social
Development [Elektronický Dokument]: 36th International Scientific Conference on Economic and Social Development "Building Resilient Society".

Pšenák, Péter, Kováč, U., Káčer, J., \& Skýpalová, M. (2018b). Women in the Slovak IT sector: From education to labor market. Economic and Social Development [Elektronický Dokument]: 36th International Scientific Conference on Economic and Social Development "Building Resilient Society".

Pšenák, Péter, \& Pšenáková, I. (2018). Az R-rel szebb a statisztika. V InfoDidact 2018 [elektronický dokument]: 11 (s. 169175). Webdidaktika Alapítvány.

Pšenák, Péter, Pšenáková, I., Szabó, T., \& Kováč, U. (2019). The Interactive Web Applications in Financial Literacy Teaching. V ICETA 2019 [elektronicky dokument]: 17th IEEE International conference on emerging elearning technologies and applications: Information and communication technologies in learning (s. 661-666). Institute of Electrical and Electronics Engineers.

Rau-Bredow, H. (2002). Credit Portfolio Modelling Marginal Risk. Contributions and Granularity Adjustment.

https://www.researchgate.net/publica tion/252683011_Credit_Portfolio_Mo delling_Marginal_Risk_Contributions_ and_Granularity_Adjustment

Sivák, R., Gertler, L., \& et al. (2018). Rizilko vo financiach a v bankovnictve (5th vyd.). Sprint 2. 